\title{
Ulinastatin post-treatment attenuates lipopolysaccharide-induced acute lung injury in rats and human alveolar epithelial cells
}

\author{
YUNPENG LUO, WEN CHE and MINGYAN ZHAO
}

\author{
Department of Intensive Care Unit, The First Affiliated Hospital of \\ Harbin Medical University, Harbin, Heilongjiang 150001, P.R. China
}

Received October 28, 2015; Accepted November 16, 2016

DOI: $10.3892 / \mathrm{ijmm} .2016 .2828$

\begin{abstract}
Ulinastatin (UTI), a serine protease inhibitor, possesses anti-inflammatory properties and has been suggested to modulate lipopolysaccharide (LPS)-induced acute lung injury (ALI). High-mobility group box 1 (HMGB1), a nuclear DNA-binding protein, plays a key role in the development of ALI. The aim of this study was to investigate whether UTI attenuates ALI through the inhibition of HMGB1 expression and to elucidate the underlying molecular mechanisms. ALI was induced in male rats by the intratracheal instillation of LPS (5 mg/kg). UTI was administered intraperitoneally $30 \mathrm{~min}$ following exposure to LPS. A549 alveolar epithelial cells were incubated with LPS in the presence or absence of UTI. An enzyme-linked immunosorbent assay was used to detect the levels of inflammatory cytokines. Western blot analysis was performed to detect the changes in the expression levels of Toll-like receptor 2/4 (TLR2/4) and the activation of nuclear factor- $\kappa \mathrm{B}(\mathrm{NF}-\kappa \mathrm{B})$. The results revealed that UTI significantly protected the animals from LPS-induced ALI, as evidenced by the decrease in the lung wet to dry weight ratio, total cells, neutrophils, macrophages and myeloperoxidase activity, associated with reduced lung histological damage. We also found that UTI post-treatment markedly inhibited the release of HMGB1 and other pro-inflammatory cytokines. Furthermore, UTI significantly inhibited the LPS-induced increase in TLR2/4 protein expression and $\mathrm{NF}-\kappa \mathrm{B}$ activation in lung tissues. In vitro, $\mathrm{UTI}$ markedly inhibited the expression of TLR2/4 and the activation of NF- $\kappa$ B in LPS-stimulated A549 alveolar epithelial cells. The findings of our study indicate that UTI attenuates LPS-induced ALI through the inhibition of HMGB1 expression in rats. These benefits are associated with the inhibition of the activation of the TLR2/4-NF- $\kappa$ B pathway by UTI.
\end{abstract}

Correspondence to: Dr Mingyan Zhao, Department of Intensive Care Unit, The First Affiliated Hospital of Harbin Medical University, 199 Dazhi Street, Nangang, Harbin, Heilongjiang 150001, P.R. China E-mail: mingyanzhao888@outlook.com

Key words: ulinastatin, lipopolysaccharide, high-mobility group box 1 , nuclear factor- $\kappa \mathrm{B}$, Toll-like receptor 2

\section{Introduction}

Acute lung injury (ALI) is a major consequence of septic shock and contributes to the high morbidity and mortality of sepsis (1). It has been demonstrated that, following severe injury or infection, some patients undergo certain responses which involve the activation of pro-inflammatory signaling pathways and the overexpression of inflammatory mediators that result in systemic inflammatory responses that culminate in severe shock, multi-organ failure and death (2). Despite extensive investigations, the cellular and molecular mechanisms that mediate ALI during septic shock remain largely unknown. Furthermore, developing effective methods for preventing and/or treating sepsis-induced ALI has proven to be difficult. A growing body of evidence suggests that there is a link between the innate immune response and ALI in several important disease states, including ischemia-reperfusion injury (3), traumatic brain injury (4) and septic shock (5).

High mobility group box 1 (HMGB1) is an evolutionarily conserved protein present in virtually all types of cells where it functions to stabilize nucleosomal structure and regulate gene expression (6). There is recent evidence suggesting that extracellular HMGB1 functions as a danger-associated molecular pattern (7) and is actively secreted by immunologically activated immune cells or is passively released from pathologically damaged cells (8). The in vivo neutralization of HMGB1 by specific antibodies has been shown to protect mice against lethal sepsis (9), as well as lipopolysaccharide (LPS)-induced ALI (10). In a more clinically relevant animal model of sepsis [induced by cecal ligation puncture (CLP)], the delayed administration of HMGB1-specific neutralizing antibodies, beginning $24 \mathrm{~h}$ after CLP, was shown to dose-dependently protect rodents from lethal sepsis (11). Moreover, the targeted inhibition of HMGB1 expression in innate immune cells (e.g., macrophages and dendritic cells) has been shown to attenuate systemic HMGB1 accumulation, and similarly to protect mice from sepsis (12). Taken together, these experimental data establish extracellular HMGB1 as a critical late mediator of experimental sepsis. In vitro studies have demonstrated that the HMGB1-stimulated inflammatory responses may be mediated through several pattern-recognition receptors, including the receptors for advanced glycation end products (13), Toll-like receptor 2 (TLR2) (14), TLR4 (15) and TLR9 (16). 
Ulinastatin (UTI) is a serine protease inhibitor that modulates innate immunity and pro-inflammatory signaling in sepsis $(17,18)$. The administration of UTI has been shown to decrease the LPS-induced increase in TLR4 expression (19), and to attenuate sepsis-induced nuclear factor $-\kappa \mathrm{B}(\mathrm{NF}-\kappa \mathrm{B})$ activity (20). Previous studies have demonstrated that UTI treatment improves the survival of mice with septis mice (21), and inhibits LPS-induced ALI in mice (19,20). Therefore, we hypothesized that UTI may downregulate HMGB1 expression and that the inhibition of HMGB1 expression may be associated with the inhibition of TLR2/4 and NF- $\kappa \mathrm{B}$ activation by UTI during sepsis. Thus, the aim of the present study was to determine whether UTI post-treatment attenuates ALI by the inhibition of HMGB1 expression in rats and human alveolar epithelial cells.

\section{Materials and methods}

Materials. LPS (Escherichia coli 055:B5) was obtained from Sigma (St. Louis, MO, USA). The HMGB1, tumor necrosis factor- $\alpha$ (TNF- $\alpha$ ), interleukin-6 (IL-6) and myeloperoxidase (MPO) enzyme-linked immunosorbent assay (ELISA) kits were obtained from Invitrogen (Carlsbad, CA, USA). Anti-TLR2 (D-17, sc-12504), anti-TLR4 (M-16, sc-12511), anti-p-NF-кB p65 (A-8, sc-166748) and anti-NF- $\mathrm{B}$ p65 (F-6, sc-8008) antibodies were obtained from Santa Cruz Biotechnology, Inc. (Santa Cruz,

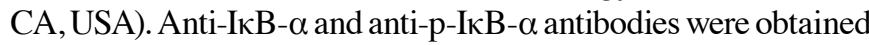
from Cell Signaling Technology, Inc. (Beverly, MA, USA).

Animals. Adult male Sprague-Dawley rats (8-10 weeks of age, weighing 250-300 g) were provided by the Experimental Animal Center of Harbin Medical University, kept in a $12 \mathrm{~h}$ dark/12 h light cycle in a temperature- and humidity-controlled room and fed standard laboratory diet and provided with water. All procedures were performed in accordance with the Declaration of Helsinki of the World Medical Association. The study was approved by the Ethics Committee of the First Affiliated Hospital of Harbin Medical University, Harbin, China.

Animalexperimentaldesign.Theanimals wererandomlydivided into 6 groups and each group contained 20 rats: i) the control group [given normal saline (NS)]; ii) the UTI $(20,000 \mathrm{U} / \mathrm{kg})$ group (administered 20,000 U/kg UTI); iii) the LPS group (rats received $5 \mathrm{mg} / \mathrm{kg}$ LPS by intratracheal instillation); iv) the $\mathrm{LPS}+\mathrm{UTI}(5,000 \mathrm{U} / \mathrm{kg}$ ) group (rats received LPS plus 5,000 U/kg $\mathrm{UTI})$; v) the LPS + UTI $(10,000 \mathrm{U} / \mathrm{kg}$ ) group (rats received LPS plus $10,000 \mathrm{U} / \mathrm{kg}$ UTI) group; vi) LPS + UTI $(20,000 \mathrm{U} / \mathrm{kg})$ group (rats received LPS plus $20,000 \mathrm{U} / \mathrm{kg} \mathrm{UTI})$. LPS $(5 \mathrm{mg} / \mathrm{kg}$; to induce ALI), or the vehicle (NS) were intratracheally administered, as previously described (22). UTI $(5,000,10,000$ or $20,000 \mathrm{U} / \mathrm{kg}$ ) was intraperitoneally injected $30 \mathrm{~min}$ after the LPS administration. The doses of these drugs were used based on previous studies $(17,19)$ and our preliminary experiments (data not shown). At $24 \mathrm{~h}$ after the LPS administration, the rats were sacrificed under sodium pentobarbitone $(45 \mathrm{mg}$ / $\mathrm{kg}$ body weight ip, Sigma) anaesthesia according to the guidelines for euthanasia in the Guide for Care and Use of Laboratory Animals, and the bronchoalveolar lavage fluid (BALF) samples were collected for counting and classification. Lung tissues were snap-frozen in liquid nitrogen, and stored at $-80^{\circ} \mathrm{C}$ for later analysis. To clarify the role of HMGB1,
TLR2/4 and NF- $\kappa$ B in LPS-induced pulmonary inflammation, the rats were administered an intraperitoneal injection of UTI (20,000 U/kg; Sigma), anti-HMGB1 antibody (MABE148; $10 \mathrm{mg} / \mathrm{kg}$ ), anti-TLR2/4 antibody (MABF84, MABF85; $10 \mathrm{mg} / \mathrm{kg}$ ) (both from Calbiochem), or the NF- $\mathrm{KB}$ inhibitor, PDTC (10 mg/kg; Sigma), $30 \mathrm{~min}$ after the LPS administration, as previously described (23). BALF was collected at $24 \mathrm{~h}$ after the LPS administration to measure the inflammatory markers.

Cell culture and treatment. The A549 human alveolar epithelial cells were obtained from the Typical Species Preservation Center of Wuhan University (Wuhan, Hubei, China). The A549 cells were seeded into 6-well plates and were cultured in Dulbecco's modified Eagle's medium (DMEM) supplemented with $10 \% \mathrm{FBS}, 100 \mathrm{U} / \mathrm{ml}$ penicillin and $100 \mu \mathrm{g} / \mathrm{ml}$ streptomycin at $37^{\circ} \mathrm{C}$ in a humidified atmosphere containing $5 \% \mathrm{CO}_{2}$. The cells were grown until $70 \%$ confluent before being subjected to the different treatments. The cells were divided into 4 groups as follows: i) the control group (NS); ii) the UTI (100 U/ml) group; iii) the LPS group (stimulated with $1 \mu \mathrm{g} / \mathrm{ml}$ LPS); and iv) the LPS + UTI (100 U/ml) group. The A549 cells were treated with UTI $(100 \mathrm{U} / \mathrm{ml}) 24 \mathrm{~h}$ after the LPS $(1 \mu \mathrm{g} / \mathrm{ml})$ stimulation. The doses of these drugs used were based on a previous study (24) and our preliminary experiments (data not shown). The cells were harvested at $24 \mathrm{~h}$ after the addition of LPS to analyze the

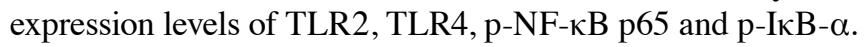

Lung wet/dry weight ratio in vivo. The water content of the lungs was determined by calculating the wet/dry weight ratio of the lung tissues. The inferior lobe of the right lung was excised, rinsed briefly in phosphate-buffered saline (PBS), blotted and then weighed to obtain the 'wet' weight. The lung was then dried at $80^{\circ} \mathrm{C}$ for $72 \mathrm{~h}$ to obtain the 'dry' weight. The wet/dry ratio was calculated by dividing the wet weight by the dry weight.

Determination of bronchoalveolar lavage proteins and cell counts. Bronchoalveolar lavage (BAL) was performed by intratracheal injection of $5 \mathrm{ml}$ ice-cold PBS followed by gentle aspiration. The recovery ratio of the fluid was $\sim 90 \%$. Then the recovered fluid was pooled and centrifuged at 1,200 $\mathrm{x} g$ for $10 \mathrm{~min}$ at $4^{\circ} \mathrm{C}$. Supernatants were preserved for the measurement of total protein concentration by the Bradford method with bovine serum albumin (BSA) as a standard. The cell pellet was re-suspended in $50 \mu \mathrm{l}$ PBS, and total cells recovered in BALF were counted. The cell differentiation was determined for 200 cells by examination of the hematoxylin and eosin (H\&E)-stained smears.

Cytokine measurements. The levels of HMGB1, TNF- $\alpha$ and IL-6 in the supernatants of BALF were measured using commercially available ELISA kits (Invitrogen) according to the manufacturer's instructions. After incubation for $1 \mathrm{~h}$ at $37^{\circ} \mathrm{C}$, the mixture of 100-ml sample and 100-ml rat HMGB1 (or TNF- $\alpha$, IL-6) biotin conjugate was added with $100 \mathrm{ml}$ streptavidin-horseradish peroxidase and incubated for another $30 \mathrm{~min}$. Then, $100 \mathrm{ml}$ stabilized chromogen was added to $100 \mathrm{ml}$ stop buffer, and the adsorption value of the mixture at $450 \mathrm{~nm}$ was measured.

MPO activity assay. The lung tissues were homogenized in 4-(2-hydroxyethyl)-1-piperazineethanesulfonic acid (HEPES; 
$\mathrm{pH}$ 8.0) containing $0.5 \%$ cetyltrimethyl ammonium bromide and subjected to three freeze-thaw cycles. The homogenate was then centrifuged $\left(4^{\circ} \mathrm{C}, 12,000 \mathrm{x} \mathrm{g}\right.$ for $\left.30 \mathrm{~min}\right)$. The MPO activity was assayed using a commercially available ELISA kit (Invitrogen). The samples were diluted in phosphate citrate buffer ( $\mathrm{pH}$ 5.0) and the absorbance of the sample was measured at $460 \mathrm{~nm}$ using a microplate reader (Model 550; Bio-Rad Laboratories, Hercules, CA, USA). The specific of MPO activity in the lungs is expressed as unit/gram of the tissue.

Histological examination. The right lobes were excised and fixed with $10 \%$ neutral phosphate-buffered formalin, imbedded in paraffin and sliced. Following H\&E staining, pathological changes of lung tissues were observed under a light microscope (BXFM; Olympus, Tokyo, Japan). The standard lung injury score performed by a blinded pathologist to objectively quantify the lung injury.

Western blot analysis. Protein concentrations were determined using a BCA protein assay kit, and $20 \mu \mathrm{g}$ proteins were loaded per well on a $10 \%$ sodium dodecylsulfate-polyacrylamide gel and transferred onto polyvinylidene difluoride membranes (Millipore, Bedford, MA, USA). After being blocked for $3 \mathrm{~h}$ in Tris-buffered saline with $0.1 \%$ Tween-20 (TBST) and 3\% BSA, the membranes were incubated overnight at $4^{\circ} \mathrm{C}$ with primary antibodies in TBST containing 3\% BSA. The membranes were then washed and incubated with horseradish peroxidase-conjugated secondary antibodies (1662408; Bio-Rad Laboratories) in TBST for $2 \mathrm{~h}$ and developed using an ECL detection system (Amersham, Buckinghamshire, UK). The density of the bands on the membranes was scanned and analyzed using an image analyzer (Lab Works Software; UVP Bioimaging Systems Upland, CA, USA).

Protein extraction. For preparing whole cell lysates, the cells were lysed in radioimmune precipitation assay (RIPA) buffer supplemented with protease inhibitor cocktail (Roche Diagnostics). Nuclear and cytoplasmic fractionations were created using the Proteo JET ${ }^{\mathrm{TM}}$ Cytoplasmic and Nuclear Protein Extraction kit (Fermentas Life Science, St. Leon-Rot, Germany) according to the instructions provided by the manufacturer.

Electrophoretic mobility shift assay (EMSA). Nuclear extracts were prepared as described above. Oligonucleotides corresponding to the NF- $\kappa B$ (5'-AGTTGAGGGGACTTTCCCA GGC-3') binding site consensus sequences were synthesized and end-labeled with biotin by Invitrogen. EMSAs were performed using the LightShift chemiluminescent EMSA kit (Pierce, Rockford, IL, USA).

Statistical analysis. Data are presented as the means \pm standard deviation (SD) of results obtained from 20 rats in each group in vivo and 3 replicates in vitro. Statistical analysis of the results was carried out by one-way analysis of variance (ANOVA) followed by Tukey's post hoc test with SPSS 11.0 software (SPSS, Inc., Chicago, IL, USA). Differences between each group were assessed by two-way analysis of variance followed by Newman-Keuls tests. P-values $<0.05$ were considered to indicate statistically significant differences.
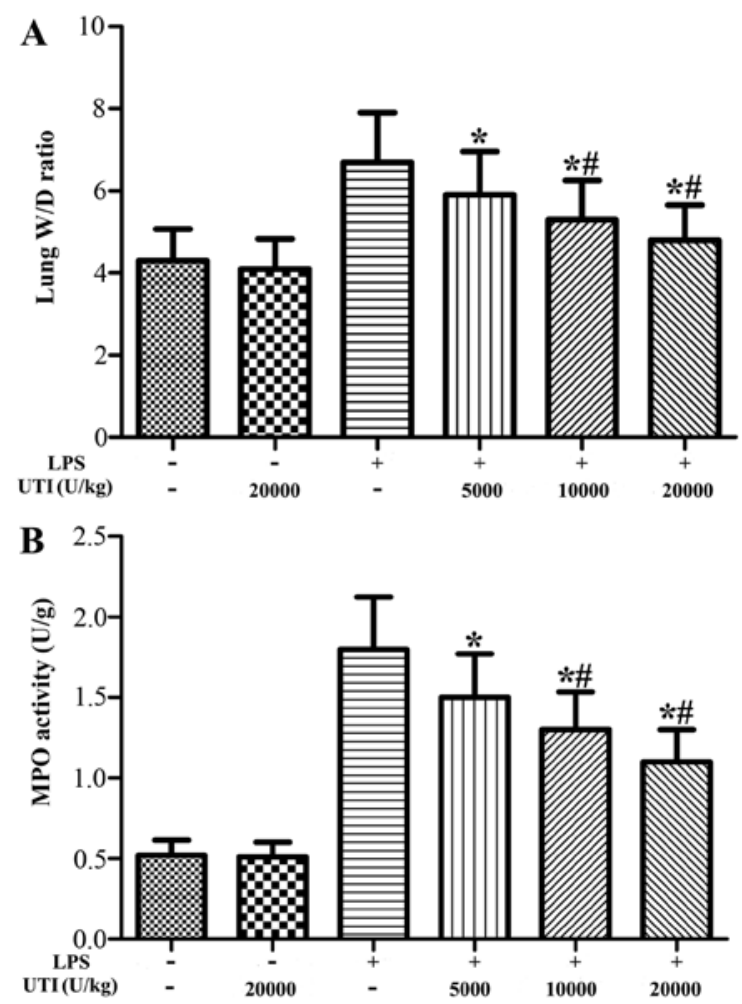

Figure 1. Ulinastatin (UTI) post-treatment reduces the lung wet/dry weight ratio and myeloperoxidase (MPO) activity in rats with lipopolysaccharide (LPS)-induced acute lung injury (ALI). Rats were administered an intraperitoneal injection of UTI $(5,000,10,000$ or $20,000 \mathrm{U} / \mathrm{kg}) 30 \mathrm{~min}$ after the LPS injection. (A) The lung wet/dry weight ratio and (B) the MPO activity were determined at $24 \mathrm{~h}$ after the LPS administration. The data are presented as the means $\pm \mathrm{SD}$ ( $\mathrm{n}=20$ rats per group). ${ }^{*} \mathrm{P}<0.05$ compared with the LPS group; ${ }^{\#} \mathrm{P}<0.01$ compared with the LPS group.

\section{Results}

Effects of UTI on the lung wet/dry weight ratio and MPO activity in lung tissues. To evaluate the LPS-induced changes in pulmonary vascular permeability and neutrophil infiltration, the lung wet/dry weight ratio and MPO activity in the lung tissues were analyzed. The lung wet/dry ratio and MPO activity in the lung tissues were significantly increased after the LPS challenge compared with the control group (Fig. 1). However, UTI post-treatment obviously attenuated the wet/dry ratio and MPO activity in lung tissues in a dose-dependent manner $(\mathrm{P}<0.05)$ (Fig. 1). There were no significant differences in the lung wet/dry ratio and MPO activity in lung tissues between the control and UTI group (UTI only).

Effects of UTI on LPS-mediated lung histopathological changes. To evaluate the histological changes following UTI post-treatment in LPS-challenged rats, the lung tissues were harvested at $24 \mathrm{~h}$ after the administration of LPS. The lung tissues from the control group exhibited a normal structure and no histopathological changes were observed (Fig. 2A). In the LPS group, histological examination revealed severe lung destruction, as indicated by $\mathrm{H} \& \mathrm{E}$ staining, which manifested as severe pulmonary edema, hemorrhagia in the stroma, alveolar collapse and mass inflammatory cell infiltration (Fig. 2C). However, UTI post-treatment effectively alleviated the 
A
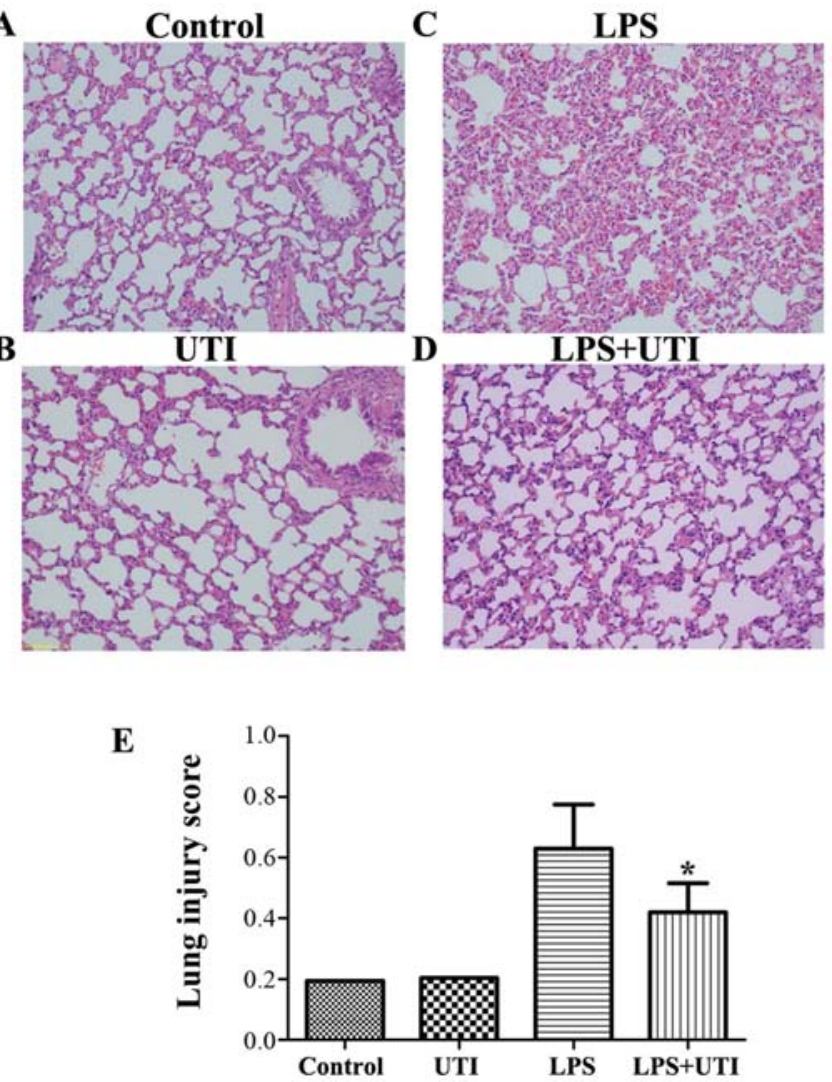

Figure 2. Histological assessment of the effects of ulinastatin (UTI) on lipopolysaccharide (LPS)-induced acute lung injury (ALI). Rats were administered an intraperitoneal injection of UTI $(20,000 \mathrm{U} / \mathrm{kg}) 30 \mathrm{~min}$ after the LPS administration. Lungs from each experimental group were processed for histological evaluation at $24 \mathrm{~h}$ after the LPS administration. (A) Control group, (B) UTI (20,000 U/kg) group, (C) LPS group, (D) LPS + UTI (20,000 U/kg) group (H\&E staining, magnification, x200), (E) Lung injury index. The data are presented as the means $\pm \mathrm{SD}$ ( $\mathrm{n}=20$ rats per group). ${ }^{*} \mathrm{P}<0.05$ compared with the LPS group.

destruction of lung structure (Fig. 2D). Furthermore, the UTI post-treatment group had a significantly lower lung injury score than the control group $(\mathrm{P}<0.05)($ Fig. 2E).

Effects of UTI on the concentration of total protein and the inflammatory cell counts in BALF. To examine the effects of UTI on LPS-induced pulmonary inflammation, the concentration of total protein and the numbers of inflammatory cells, such as neutrophils and macrophages, in BALF were analyzed at $24 \mathrm{~h}$ after the LPS injection. After the LPS challenge, the concentration of total protein and the numbers of total cells, neutrophils and macrophages significantly increased compared with the control group (Fig. 3). However, this increase was apparently attenuated by UTI post-treatment in a dose-dependent manner $(\mathrm{P}<0.05)$ (Fig. 3).

Effects of UTI on the concentrations of HMGBI,TNF- $\alpha$ and $I L-6$ in $B A L F$. To further evaluate the anti-inflammatory effects of UTI, the concentrations of the pro-inflammatory cytokines, TNF- $\alpha$, IL- 6 and HMGB1, in BALF were analyzed at $24 \mathrm{~h}$ after the LPS administration by ELISA. The concentrations of TNF- $\alpha$, IL- 6 and HMGB1 in BALF significantly increased in the LPS group (Fig. 4). However, UTI post-treatment

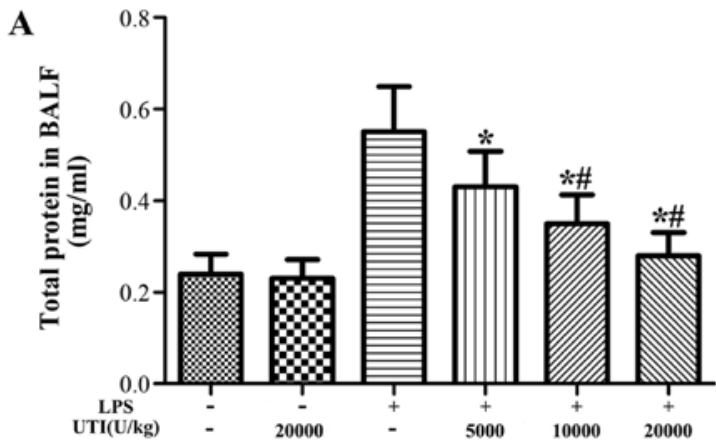

B
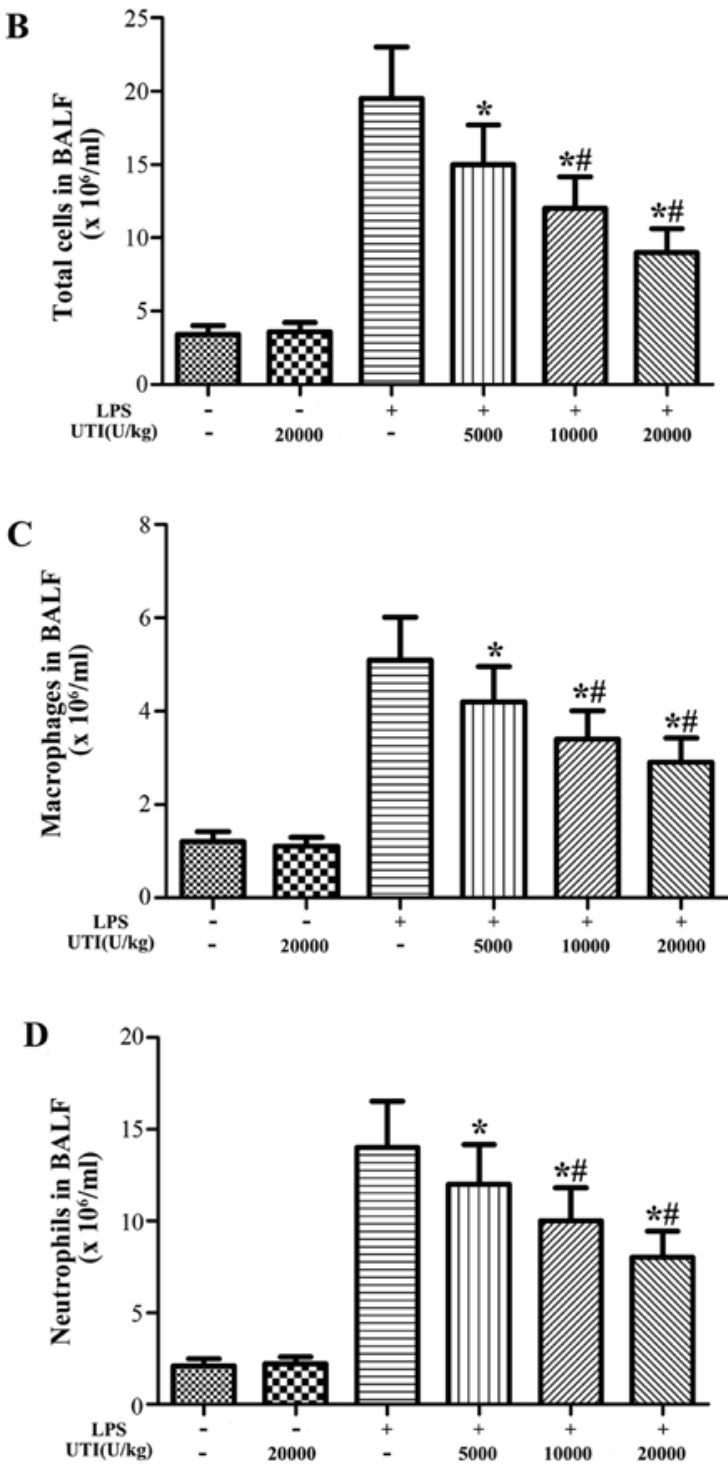

Figure 3. Effects of ulinastatin (UTI) on the total protein concentration and the numbers of total cells, neutrophils and macrophages in BALF. Rats were given an intraperitoneal injection of UTI $(5,000,10,000$ or $20,000 \mathrm{U} / \mathrm{kg})$ $30 \mathrm{~min}$ after the lipopolysaccharide (LPS) administration. BALF was collected at $24 \mathrm{~h}$ after the LPS administration to measure (A) the total protein concentration and (B) the number of total cells, (C) macrophages and (D) neutrophils. The data are presented as the means $\pm \mathrm{SD}$ ( $\mathrm{n}=20$ rats per group). ${ }^{*} \mathrm{P}<0.05$ compared with the LPS group; ${ }^{\#} \mathrm{P}<0.01$ compared with the LPS group.

markedly decreased the levels of TNF- $\alpha$, IL- 6 and HMGB1 compared to those in the LPS group in a dose-dependent manner $(\mathrm{P}<0.05)$ (Fig. 4). 

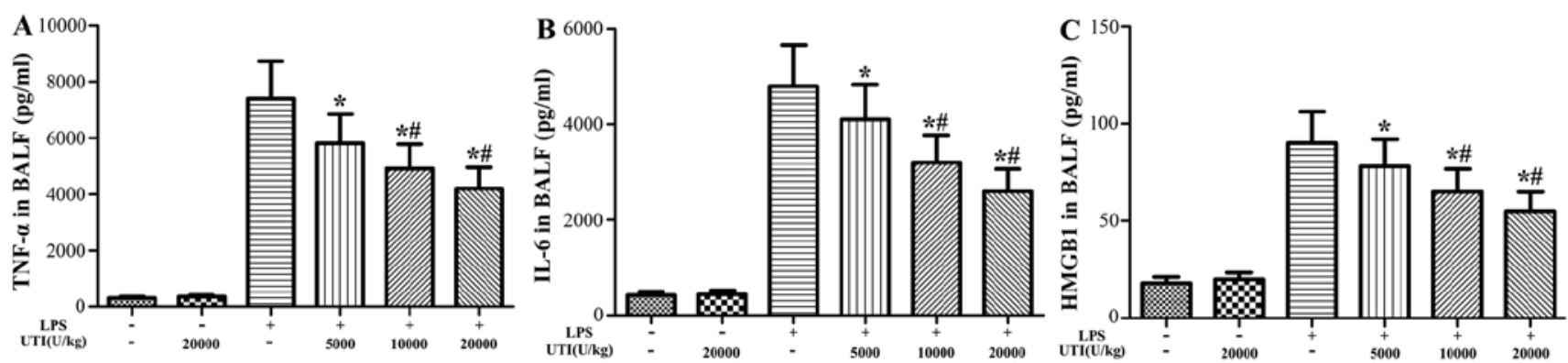

Figure 4. Ulinastatin (UTI) post-treatment inhibits the lipopolysaccharide (LPS)-induced increase in the expression of tumor necrosis factor- $\alpha$ (TNF- $\alpha$ ), interleukin-6 (IL-6) and high-mobility group box 1 (HMGB1) in BALF. Rats were administered an intraperitoneal injection of UTI $(5,000,10,000$ or 20,000 U/kg) $30 \mathrm{~min}$ after the LPS administration. BALF was collected at $24 \mathrm{~h}$ after the LPS administration to analyze the inflammatory cytokines (A) TNF- $\alpha$, (B) IL-6 and (C) HMGB1. The data are presented as the means $\pm \mathrm{SD}$ ( $\mathrm{n}=20$ rats per group). ${ }^{*} \mathrm{P}<0.05$ compared with the LPS group; ${ }^{\text {"P }}<0.01$ compared with the LPS group.
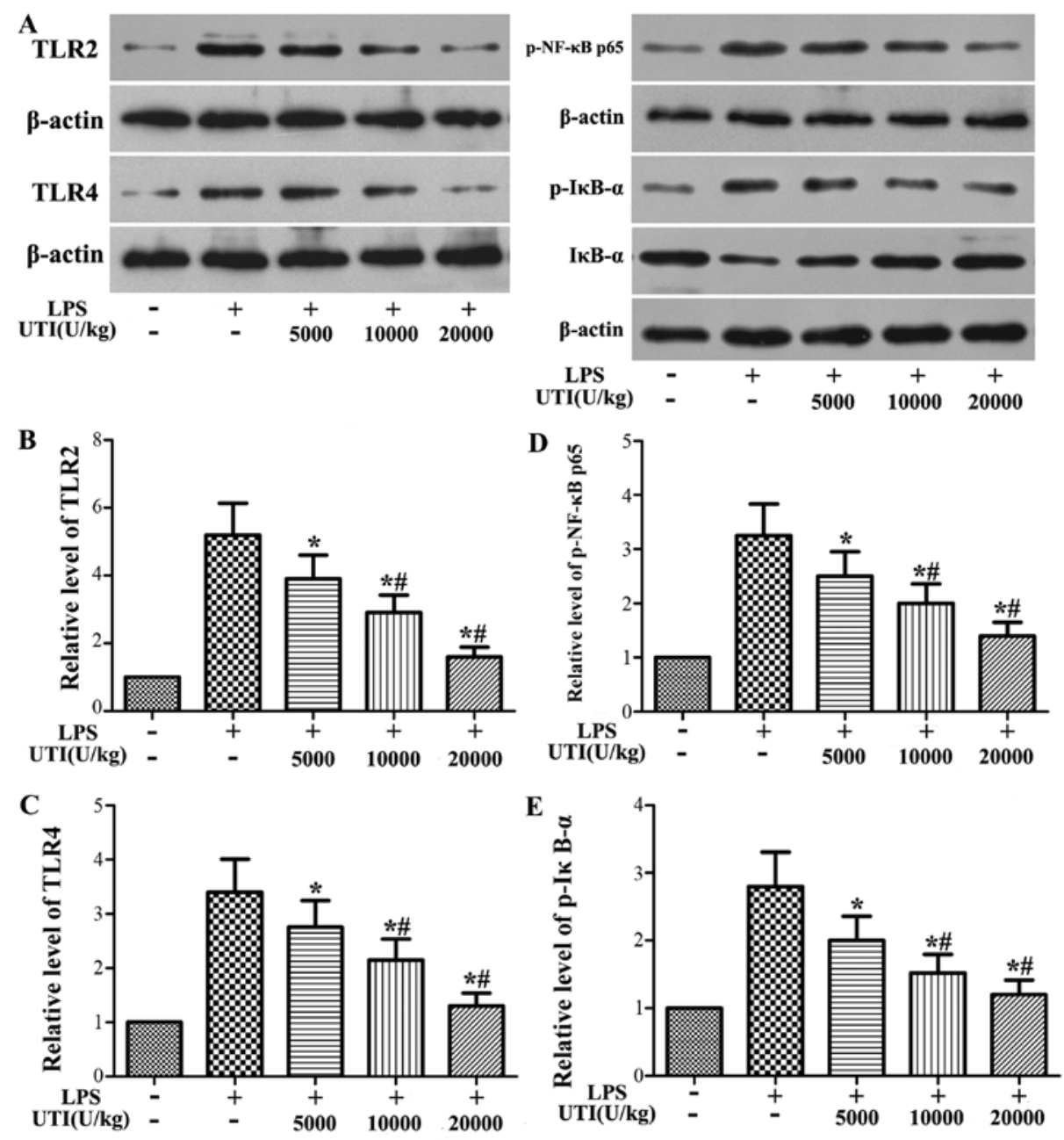

Figure 5. Ulinastatin (UTI) post-treatment inhibits the expression of Toll-like receptor 2/4 (TLR2/4) and the phosphorylation of nuclear factor- $\kappa$ B (NF- $\kappa$ B) p65

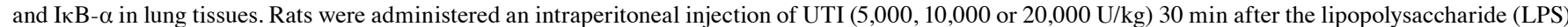
administration. At $24 \mathrm{~h}$ after the LPS administration, the expression levels of (B) TLR2 and (C) TLR4 and (D) the phosphorylation of NF- $\kappa \mathrm{B}$ p65 and (E) I $\mathrm{B}$ - $\alpha$ were detected by western blot analysis. The representative blots are shown in (A) The data are presented as the means \pm SD ( $=20$ rats per group). ${ }^{*}<0.05$ compared with the LPS group; ${ }^{\#} \mathrm{P}<0.01$ compared with the LPS group.

Effects of UTI on the expression levels of TLR2/4 and the activation of $N F-\kappa B$ in lung tissues. Western blot analysis was used to determine the expression levels of TLR2/4 and the phosphorylation of NF-kB p65 and IкB- $\alpha$. The protein levels of TLR2/4 and the phosphorylation levels of NF-kB p65 and I $\mathrm{B}-\alpha$ significantly increased in the LPS group at $24 \mathrm{~h}$ after the
LPS administration (Fig. 5). However, this increase was apparently attenuated by UTI post-treatment in a dose-dependent manner $(\mathrm{P}<0.05)$ (Fig. 5).

Effects of UTI on the expression levels of TLR2/4 and the activation of NF- $\kappa B$ in A549 alveolar epithelial cells. To further 
A
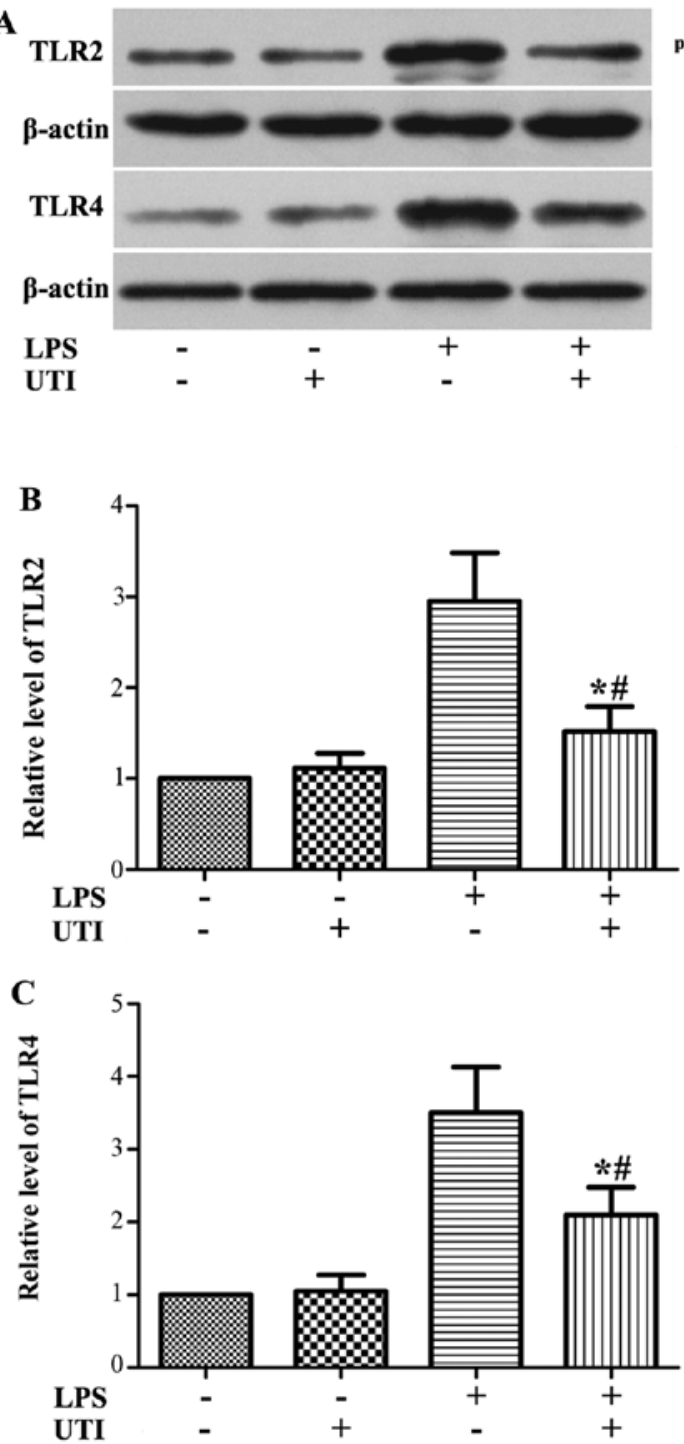

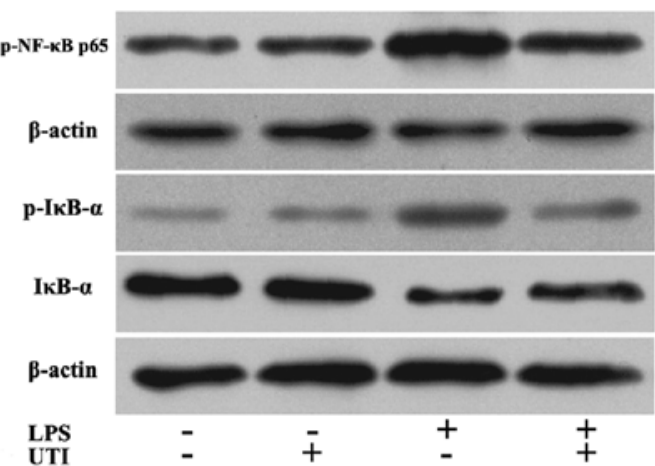

D

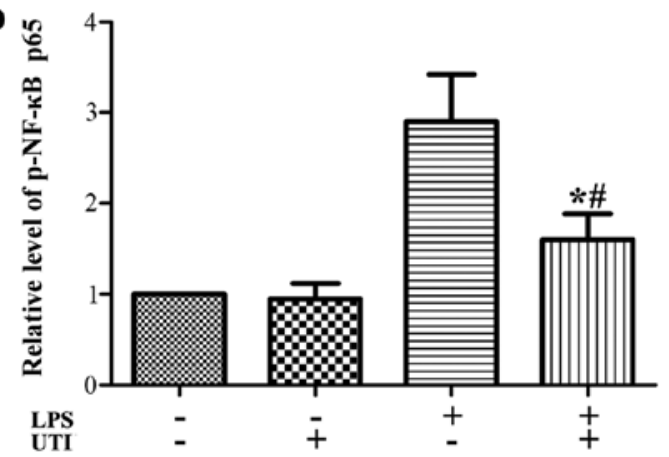

$\mathbf{E}$

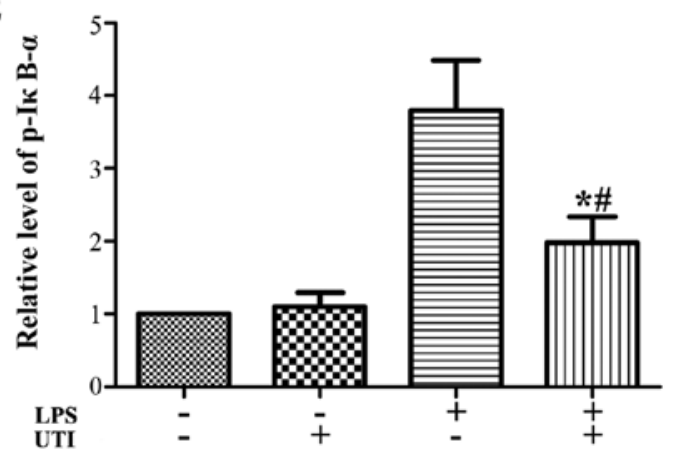

Figure 6. Ulinastatin (UTI) post-treatment inhibits the expression of Toll-like receptor 2/4 (TLR2/4) and the phosphorylation of nuclear factor- $\kappa \mathrm{B}$ (NF- $\kappa \mathrm{B}$ ) p65 and I $\kappa$ B- $\alpha$ in lipopolysaccharide (LPS)-stimulated A549 alveolar epithelial cells. A549 cells were treated with UTI (100 U/ml) $24 \mathrm{~h}$ after LPS (1 $\mu \mathrm{g} / \mathrm{ml})$ stimulation. The expression levels of (A and B) TLR2 and (A and C) TLR4 and (A and D) the phosphorylation of NF- $\kappa$ B p65 and (A and E) I $\kappa$ - $\alpha$ were detected by western blot analysis. Data are presented as the means \pm SD from 3 independent experiments. ${ }^{*} \mathrm{P}<0.05$ compared with the LPS group; ${ }^{\prime} \mathrm{P}<0.01$ compared with the LPS group.

examine the anti-inflammatory mechanistic basis of UTI, we examined the effects of UTI on TLR $2 / 4$ expression and NF- $\kappa \mathrm{B}$ activation in A549 alveolar epithelial cells. Similar to what we observed in the animal experiments, the expression levels of TLR2/4 and the phosphorylation of NF- $\kappa$ B p65 and I $\mathrm{B}-\alpha$ were markedly increased in the cells stimulated with LPS. However, these increases were markedly inhibited by UTI posttreatment $(\mathrm{P}<0.05)$ (Fig. 6).

Effects of anti-HMGB1 antibody and UTI on inflammatory markers in BALF of LPS-induced ALI. To clarify the role of HMGB1 in LPS-induced pulmonary inflammation, the rats were administered an intraperitoneal injection of UTI $(20,000 \mathrm{U} / \mathrm{kg})$ or anti-HMGB1 antibody $(10 \mathrm{mg} / \mathrm{kg}) 30 \mathrm{~min}$ after the LPS administration. BALF was collected at $24 \mathrm{~h}$ after the LPS administration to measure the inflammatory markers. After the LPS challenge, the levels of inflammatory markers significantly increased compared with the control group (Fig. 7). However, this increase was markedly attenuated by anti-HMGB1 anti- body $(\mathrm{P}<0.05)$ (Fig. 7). Furthermore, anti-HMGB1 antibody significantly enhanced the anti-inflammatory effects of UTI on inflammatory markers in BALF from rats with LPS-induced ALI $(\mathrm{P}<0.05)$ (Fig. 7).

Effects of anti-TLR2 antibody and UTI on inflammatory markers in BALF from rats with LPS-induced ALI. To clarify the role of TLR2 in LPS-induced pulmonary inflammation, rats were administered an intraperitoneal injection of UTI $(20,000 \mathrm{U} / \mathrm{kg})$ or anti-TLR2 antibody $(10 \mathrm{mg} / \mathrm{kg}) 30 \mathrm{~min}$ after the LPS administration. BALF was collected at $24 \mathrm{~h}$ after the LPS administration to measure the inflammatory markers. After the LPS challenge, the levels of inflammatory markers significantly increased compared with the control group (Fig. 8). However, this increase was markedly attenuated by anti-TLR2 antibody $(\mathrm{P}<0.05)$ (Fig. 8). Furthermore, antiTLR2 antibody significantly enhanced the anti-inflammatory effects of UTI on inflammatory markers in BALF from rats with LPS-induced ALI (P<0.05) (Fig. 8). 

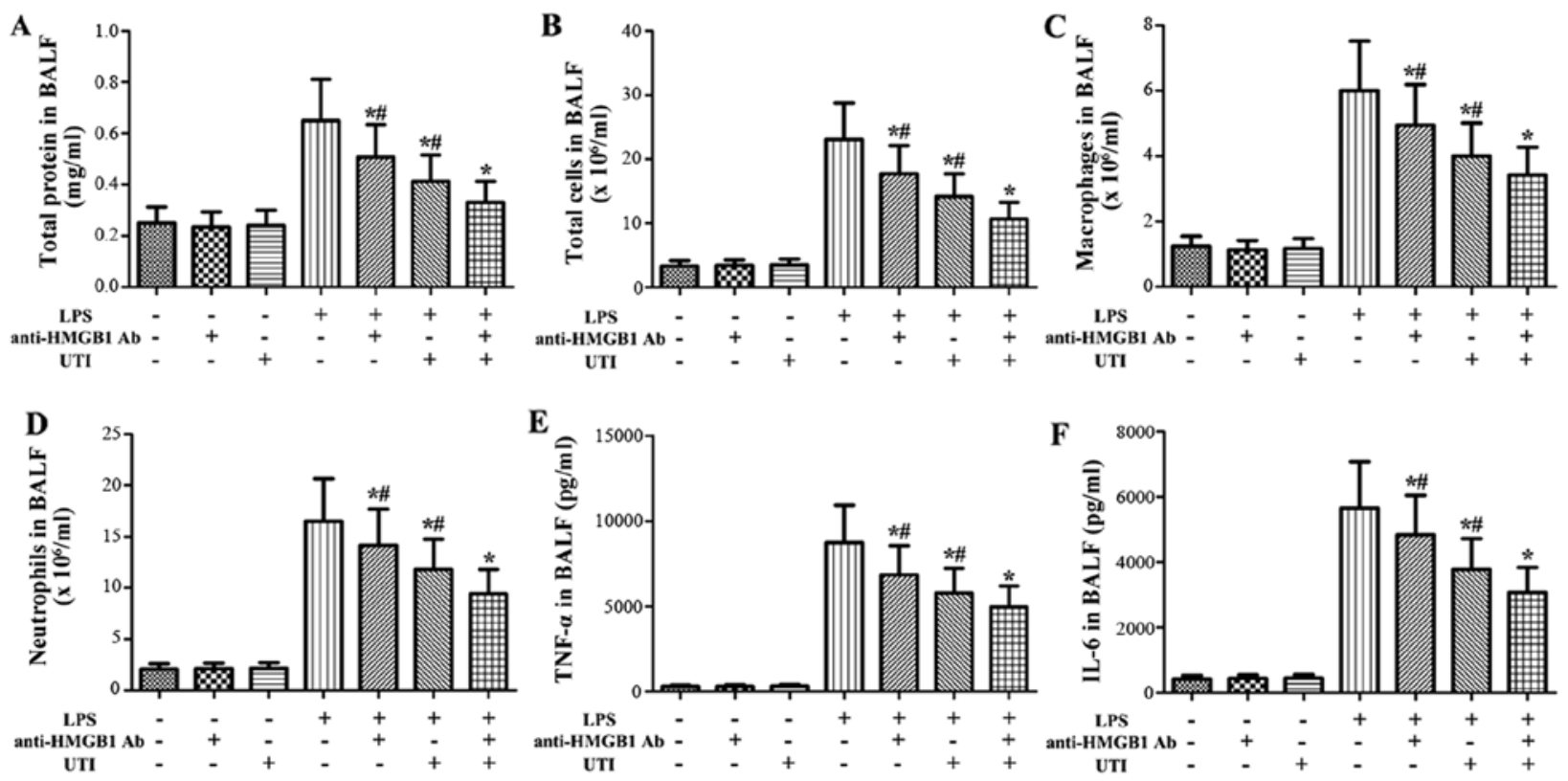

Figure 7. Effects of anti-high-mobility group box 1 (HMGB1) antibody (Ab) and ulinastatin (UTI) on inflammatory markers in BALF from rats with lipopolysaccharide (LPS)-induced acute lung injury (ALI). Rats were administered an intraperitoneal injection of UTI (20,000 U/kg) or anti-HMGB1 Ab (10 mg/kg) $30 \mathrm{~min}$ after the LPS administration. BALF was collected at $24 \mathrm{~h}$ after the LPS administration to measure (A) the total protein concentration, (B) the numbers of total cells, (C) macrophages and (D) neutrophils, and the inflammatory cytokines (E) tumor necrosis factor- $\alpha$ (TNF- $\alpha$ ) and (F) interleukin-6 (IL-6). The data are presented as the means $\pm \mathrm{SD}$ ( $\mathrm{n}=20$ rats per group). ${ }^{*} \mathrm{P}<0.05$ compared with the LPS group; ${ }^{\text {}} \mathrm{P}<0.05$ compared with the LPS $+\mathrm{UTI}(20,000 \mathrm{U} / \mathrm{kg})+$ antiHMGB1 Ab (10 mg/kg) group.
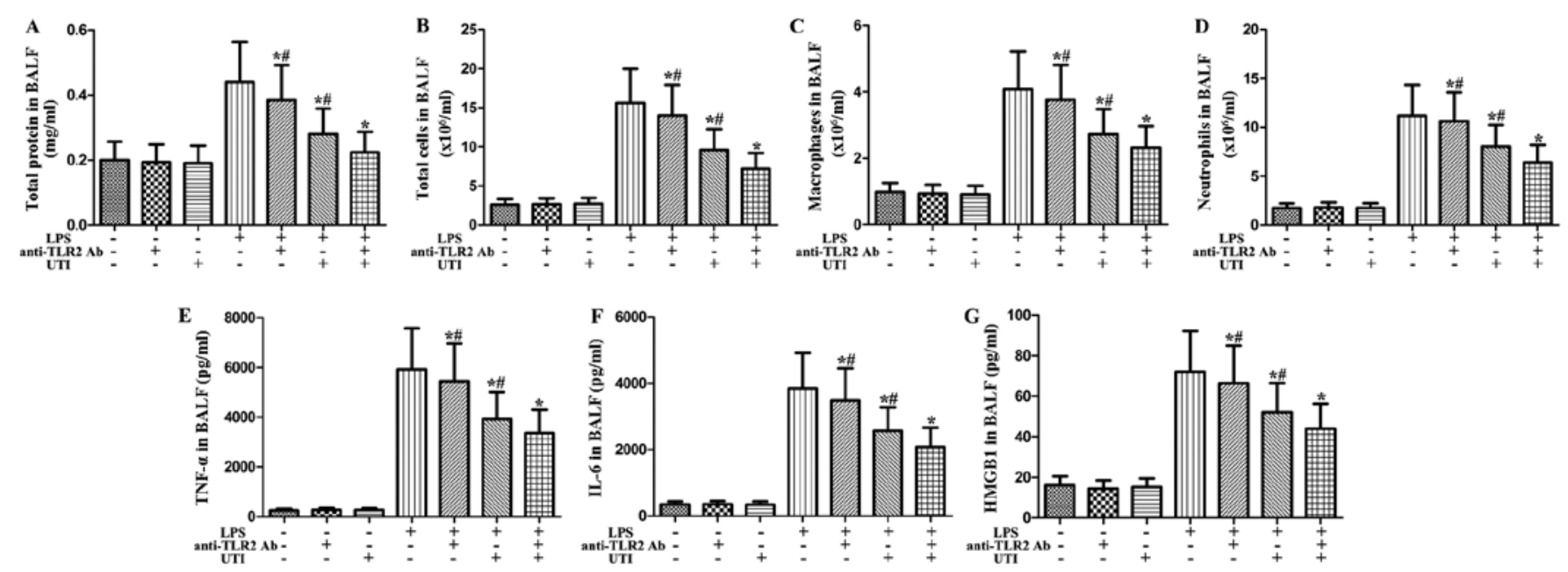

Figure 8. Effects of anti-Toll-like receptor 2 (TLR2) antibody (Ab) and ulinastatin (UTI) on inflammatory markers in BALF from rats with lipopolysaccharide (LPS)-induced acute lung injury (ALI). Rats were administered an intraperitoneal injection of UTI (20,000 U/kg) or anti-TLR2 Ab (10 mg/kg) $30 \mathrm{~min}$ after the LPS administration. BALF was collected at $24 \mathrm{~h}$ after the LPS administration to measure (A) the total protein concentration, (B) the numbers of total cells, (C) macrophages and (D) neutrophils, and the inflammatory cytokines (E) tumor necrosis factor- $\alpha$ (TNF- $\alpha$ ), (F) interleukin-6 (IL-6) and (G) high-mobility group box 1 (HMGB1). The data are presented as the means $\pm \mathrm{SD}$ ( $\mathrm{n}=20$ rats per group). ${ }^{*} \mathrm{P}<0.05$ compared with the LPS group; ${ }^{*} \mathrm{P}<0.05$ compared with the LPS + UTI $(20,000 \mathrm{U} / \mathrm{kg})+$ anti-TLR2 Ab $(10 \mathrm{mg} / \mathrm{kg})$ group.

Effects of anti-TLR4 antibody and UTI on inflammatory markers in BALF from rats with LPS-induced ALI. To clarify the role of TLR4 in LPS-induced pulmonary inflammation, rats were administered an intraperitoneal injection of UTI $(20,000 \mathrm{U} / \mathrm{kg})$ or anti-TLR4 antibody $(10 \mathrm{mg} / \mathrm{kg}) 30 \mathrm{~min}$ after the LPS administration. BALF was collected at $24 \mathrm{~h}$ after the LPS administration to measure the levels of inflammatory markers. As shown in Fig. 9, after the LPS challenge, the levels of inflammatory markers significantly increased compared with the control group. However, this increase was markedly attenuated by anti-TLR4 antibody $(\mathrm{P}<0.05)$ (Fig. 9). Furthermore, anti-TLR4 antibody significantly enhanced the anti-inflammatory effects of UTI on inflammatory markers in BALF from rats with LPS-induced ALI ( $\mathrm{P}<0.05)$ (Fig. 9).

Effects of $N F-\kappa B$ inhibitor and UTI on inflammatory markers in BALF from rats with LPS-induced ALI. To clarify the role of NF- $\kappa \mathrm{B}$ in LPS-induced pulmonary inflammation, rats were 


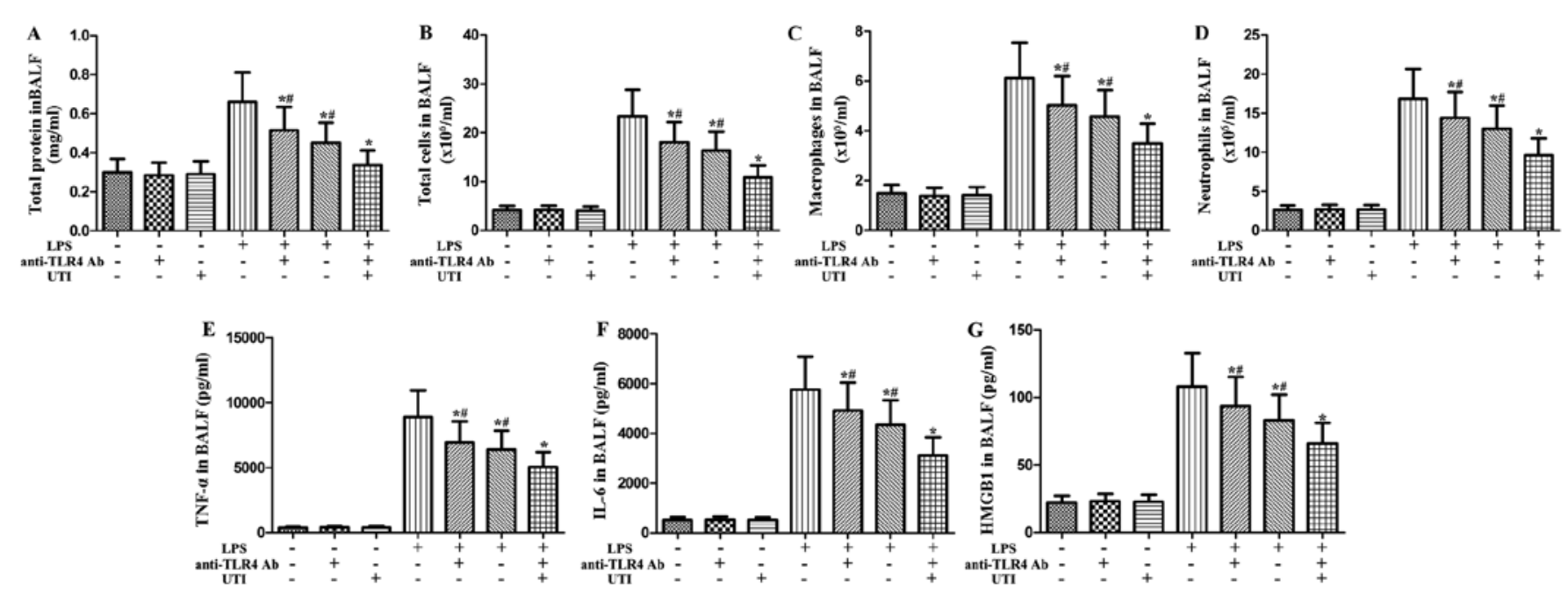

Figure 9. Effects of anti-TLR4 antibody (Ab) and ulinastatin (UTI) on inflammatory markers in BALF from rats with LPS-induced ALI. Rats were administered an intraperitoneal injection of UTI $(20,000 \mathrm{U} / \mathrm{kg})$ or anti-TLR4 $\mathrm{Ab}(10 \mathrm{mg} / \mathrm{kg}) 30 \mathrm{~min}$ after the LPS administration. BALF was collected at $24 \mathrm{~h}$ after the LPS administration to measure (A) the total protein concentration, (B) the numbers of total cells, (C) macrophages and (D) neutrophils, and the inflammatory cytokines, (E) tumor necrosis factor (TNF)- $\alpha,(\mathrm{F})$ interleukin (IL)-6 and (G) high-mobility group box 1 (HMGB1). The data are presented as the means \pm SD. (n=20 rats per group). ${ }^{\text {P }}<0.05$ compared with the LPS group; ${ }^{*} \mathrm{P}<0.05$ compared with the LPS + UTI (20,000 U/kg) + anti-TLR4 Ab (10 mg/kg) group.
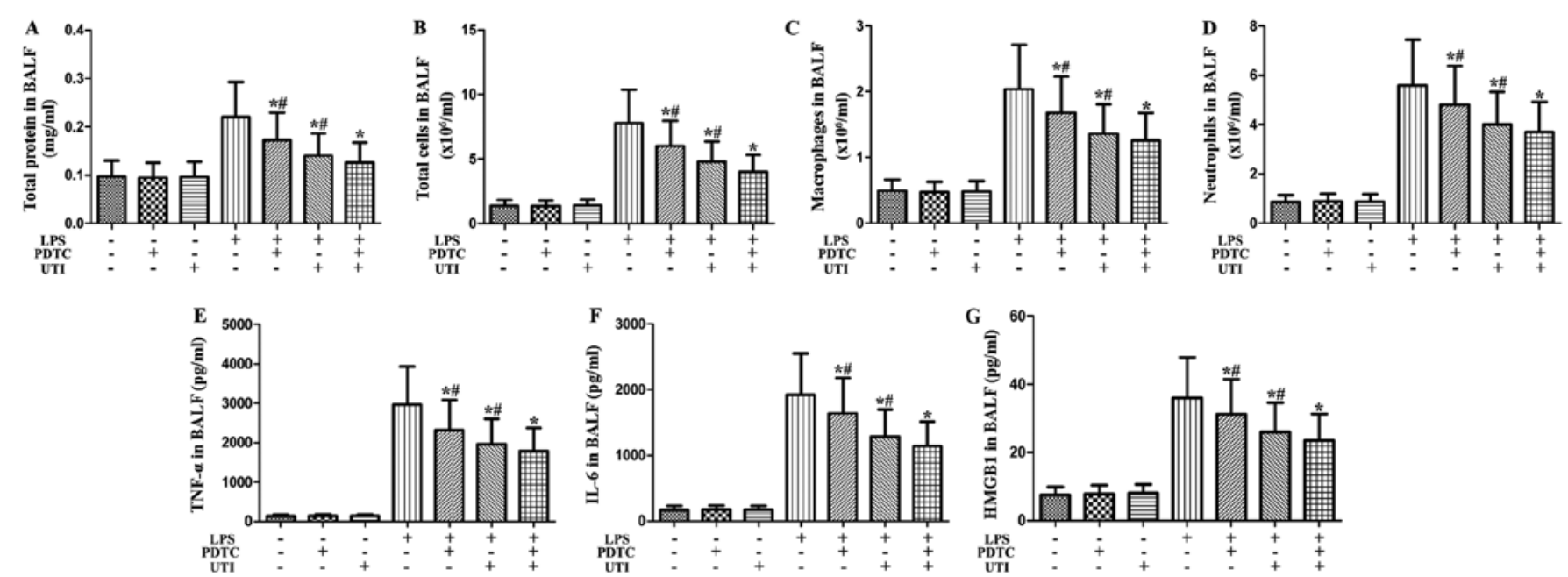

Figure 10. Effects of nuclear factor- $\kappa \mathrm{B}(\mathrm{NF}-\kappa \mathrm{B})$ inhibitor and ulinastatin (UTI) on inflammatory markers in BALF from rats with lipopolysaccharide (LPS)induced acute lung injury (ALI). Rats were administered an intraperitoneal injection of UTI (20,000 U/kg) or the NF- $\mathrm{BB}$ inhibitor, PDTC, (10 mg/kg) $30 \mathrm{~min}$ after the LPS administration. BALF was collected at $24 \mathrm{~h}$ after the LPS administration to measure (A) the total protein concentration, (B) the numbers of total cells, (C) macrophages and (D) neutrophils, and the inflammatory cytokines, (E) tumor necrosis factor- $\alpha$ (TNF- $\alpha$ ), (F) interleukin-6 (IL-6) and (G) highmobility group box 1 (HMGB1). The data are presented as the means $\pm \mathrm{SD}$ ( $\mathrm{n}=20$ rats per group). ${ }^{*} \mathrm{P}<0.05$ compared with the LPS group; ${ }^{*} \mathrm{P}<0.05$ compared with the LPS group; ${ }^{\text {P }}<0.05$ compared with the LPS + UTI $(20,000 \mathrm{U} / \mathrm{kg})+\mathrm{NF}-\kappa \mathrm{B}$ inhibitor PDTC $(10 \mathrm{mg} / \mathrm{kg}) \mathrm{group}$.

administered an intraperitoneal injection of UTI $(20,000 \mathrm{U} / \mathrm{kg})$ or NF- $\mathrm{KB}$ inhibitor PDTC $(10 \mathrm{mg} / \mathrm{kg}) 30 \mathrm{~min}$ after the LPS administration. BALF was collected at $24 \mathrm{~h}$ after the LPS administration to measure the inflammatory markers. After the LPS challenge, the levels of inflammatory markers significantly increased compared with the control group (Fig. 10). However, this increase was markedly attenuated by the NF- $\kappa B$ inhibitor, PDTC $(\mathrm{P}<0.05)$ (Fig. 10). Furthermore, the NF-кB inhibitor, PDTC, significantly enhanced the anti-inflammatory effects of UTI on inflammatory markers in BALF from rats with LPS-induced ALI ( $\mathrm{P}<0.05)$ (Fig. 10).

UTI post-treatment inhibits $N F-\kappa B D N A$ binding activity in lung tissues. To determine the effects of UTI on transcrip- tion factor signaling pathways that may mediate LPS-induced inflammatory cytokine production, EMSA was performed. The rats were admininstered an intraperitoneal injection of UTI $(20,000 \mathrm{U} / \mathrm{kg}) 30 \mathrm{~min}$ after the LPS administration. At $24 \mathrm{~h}$ after the LPS administration, nuclear extracts obtained from lung tissues were collected. Post-treatment with UTI markedly reduced the LPS-induced DNA-binding activity of NF-KB (Fig. 11).

\section{Discussion}

In this study, we evaluated the protective effects of UTI in a model of LPS-induced ALI in rats and human alveolar epithelial cells. Consistent with previously published data (20), we 


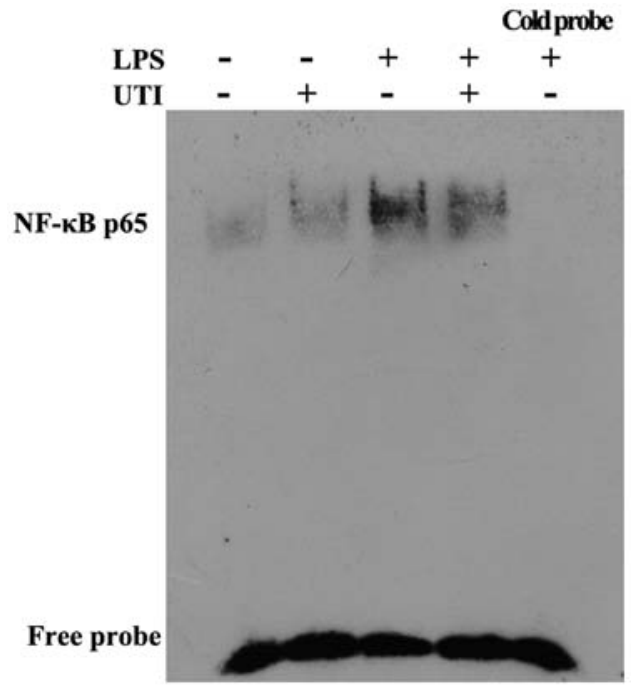

Figure 11. Ulinastatin post-treatment inhibits nuclear factor- $\kappa \mathrm{B}(\mathrm{NF}-\kappa \mathrm{B})-\mathrm{DNA}$ binding activity in lung tissues. Rats were administered an intraperitoneal injection of ulinastatin $(20,000 \mathrm{U} / \mathrm{kg}) 30 \mathrm{~min}$ after the lipopolysaccharide (LPS) administration. At $24 \mathrm{~h}$ after the LPS administration, nuclear extracts obtained from lung tissues were collected. The DNA-binding activity of NF- $\kappa \mathrm{B}$ in lung tissues was evaluated by electrophoretic mobility shift assay (EMSA). Results were confirmed by 3 independent experiments.

demonstrated that UTI post-treatment attenuated lung inflammatory injury following LPS challenge, as revealed by the decreased elevation of the lung wet to dry weight ratio, total cells, neutrophils, macrophages and MPO activity, associated with reduced lung histological damage. In addition, we also found that UTI post-treatment markedly inhibited the release of HMGB1 and other pro-inflammatory cytokines in a rat model of LPS-induced ALI. Furthermore, UTI significantly inhibited the LPS-induced increase in TLR2/4 protein expression and $\mathrm{NF}-\kappa \mathrm{B}$ activation in vivo and in vitro.

Previous studies have demonstrated that UTI inhibits the inflammatory response and mitigates sepsis-induced ALI $(18,20)$. As is already known, the etiologies of ALI are complex, and additional mechanisms through which UTI exerts protective effects against LPS-induced lung injury need to be further investigated. Evidence suggests that HMGB1 plays a critical role in the progression of ALI. HMGB1-based therapeutic strategies may be more effective in ALI, as HMGB1 is a late inflammatory mediator, and this may provide a much broader intervention window. Therefore, the current study aimed to examine the hypothesis that UTI post-treatment alleviates LPS-induced ALI by preventing the expression of HMGB1.

Clinical and experimental studies have indicated that ALI is an early and fatal complication of septic shock (1) and that the TLR2/4-mediated NF- $\kappa \mathrm{B}$ activation signaling pathway may be an early molecular event leading to ALI during septic shock $(25,26)$. Previous studies have demonstrated that UTI significantly improved the survival of mice with septis (21) and the mechanisms involved the downregulation of the expression of TLR4 (19). To evaluate our hypothesis, we examined pulmonary inflammation in LPS-induced ALI with or without UTI post-treatment. We observed that the pulmonary inflammation was significantly increased in a rat model of LPS-induced ALI.
However, UTI post-treatment significantly inhibited pulmonary inflammation by inhibiting the expression of TLR $2 / 4$ in a rat model of LPS-induced ALI. It has been demonstrated that the administration of UTI significantly blunted NF- $\kappa$ B activation in rats with septis (18). NF- $\kappa \mathrm{B}$ is a critical transcription factor in TLR-mediated signaling pathways (27) and plays a critical role in the regulation of the expression of a number of genes, including inflammatory cytokines, such as HMGB1, TNF- $\alpha$ and IL-1 $\beta$ (28-31). In this study, we demonstrated that UTI posttreatment downregulated HMGB1 expression in a rat model of LPS-induced ALI and that the inhibition of HMGB1 expression was associated with the inhibition of TLR $2 / 4$ and NF- $\kappa$ B activation by UTI post-treatment.

UTI is a synthetic glycoprotein with a molecular weight of $67 \mathrm{kDa}$, first purified from human urine (32). It is frequently used clinically for the treatment of shock (33) and acute pancreatitis (34). According to the pharmaceutical reference of UTI, side-effects have been reported in $74 / 8,710$ patients $(0.8 \%)$ at doses up to of $3 \times 10^{5} \mathrm{U} /$ day (32). These included abnormalities in serum tests, such as elevations in liver enzyme levels, abdominal symptoms, skin rashes and angialgia after intravenous administrations (32). In this study, we found that UTI post-treatment $(5,000,10,000$ or $20,000 \mathrm{U} / \mathrm{kg})$ attenuated LPS-induced ALI in a dose-dependent manner. Due to the toxicity of systemic UTI, we consider that UTI post-treatment at $10,000 \mathrm{U} / \mathrm{kg}$ was effective and safe; however, this should be explored further in larger animal studies and more relevant sepsis models, as well as eventually, in human trials.

In conclusion, the present study provides evidence that UTI post-treatment attenuates LPS-induced ALI accompanied with a decreased HMGB1 expression in a model of LPS-induced ALI. The mechanisms responsible for these effects involve, at least in part, the downregulation of TLR2/4 expression and the inhibition of the NF- $\mathrm{B}$ pathway.

\section{References}

1. Su CF, Kao SJ and Chen HI: Acute respiratory distress syndrome and lung injury: Pathogenetic mechanism and therapeutic implication. World J Crit Care Med 1: 50-60, 2012.

2. Castellheim A, Brekke OL, Espevik T, Harboe $M$ and Mollnes TE: Innate immune responses to danger signals in systemic inflammatory response syndrome and sepsis. Scand J Immunol 69: 479-491, 2009.

3. Jing H, Yao J, Liu X, Fan H, Zhang F, Li Z, Tian X and Zhou Y: Fish-oil emulsion (omega-3 polyunsaturated fatty acids) attenuates acute lung injury induced by intestinal ischemia-reperfusion through Adenosine 5'-monophosphate-activated protein kinasesirtuin1 pathway. J Surg Res 187: 252-261, 2014.

4. Song Z, Zhao X, Gao Y, Liu M, Hou M, Jin H and Cui Y: Recombinant human brain natriuretic peptide ameliorates traumainduced acute lung injury via inhibiting JAK/STAT signaling pathway in rats. J Trauma Acute Care Surg 78: 980-987, 2015.

5. Lin WC, Chen CW, Huang YW, Chao L, Chao J, Lin YS and Lin CF: Kallistatin protects against sepsis-related acute lung injury via inhibiting inflammation and apoptosis. Sci Rep 5: 12463, 2015.

6. Lu B, Wang C, Wang M, Li W, Chen F, Tracey KJ and Wang H: Molecular mechanism and therapeutic modulation of high mobility group box 1 release and action: An updated review. Expert Rev Clin Immunol 10: 713-727, 2014.

7. Agalave NM and Svensson CI: Extracellular high-mobility group box 1 protein (HMGB1) as a mediator of persistent pain. Mol Med 20: 569-578, 2015.

8. Wang H, Ward MF and Sama AE: Targeting HMGB1 in the treatment of sepsis. Expert Opin Ther Targets 18: 257-268, 2014. 
9. Wang H, Bloom O, Zhang M, Vishnubhakat JM, Ombrellino M, Che J, Frazier A, Yang H, Ivanova S, Borovikova L, et al: HMG-1 as a late mediator of endotoxin lethality in mice. Science 285 : 248-251, 1999

10. Lutz W and Stetkiewicz J: High mobility group box 1 protein as a late-acting mediator of acute lung inflammation. Int J Occup Med Environ Health 17: 245-254, 2004.

11. Yang H, Ochani M, Li J, Qiang X, Tanovic M, Harris HE, Susarla SM, Ulloa L, Wang H, DiRaimo R, et al: Reversing established sepsis with antagonists of endogenous high-mobility group box 1. Proc Natl Acad Sci USA 101: 296-301, 2004.

12. Ye C, Choi JG, Abraham S, Wu H, Diaz D, Terreros D, Shankar P and Manjunath N: Human macrophage and dendritic cell-specific silencing of high-mobility group protein B1 ameliorates sepsis in a humanized mouse model. Proc Natl Acad Sci USA 109: 21052-21057, 2012.

13. van Beijnum JR, Buurman WA and Griffioen AW: Convergence and amplification of toll-like receptor (TLR) and receptor for advanced glycation end products (RAGE) signaling pathways via high mobility group B1 (HMGB1). Angiogenesis 11: 91-99, 2008

14. Park JS, Gamboni-Robertson F, He Q, Svetkauskaite D, Kim JY, Strassheim D, Sohn JW, Yamada S, Maruyama I, Banerjee A, et al: High mobility group box 1 protein interacts with multiple Toll-like receptors. Am J Physiol Cell Physiol 290: C917-C924, 2006.

15. Kim S, Kim SY, Pribis JP, Lotze M, Mollen KP, Shapiro R, Loughran P, Scott MJ and Billiar TR: Signaling of high mobility group box 1 (HMGB1) through toll-like receptor 4 in macrophages requires CD14. Mol Med 19: 88-98, 2013.

16. Hirata Y, Kurobe H, Higashida M, Fukuda D, Shimabukuro M, Tanaka K, Higashikuni Y, Kitagawa T and Sata M: HMGB1 plays a critical role in vascular inflammation and lesion formation via toll-like receptor 9. Atherosclerosis 231: 227-233, 2013.

17. Cao YZ, Tu YY, Chen X, Wang BL, Zhong YX and Liu MH Protective effect of Ulinastatin against murine models of sepsis: Inhibition of TNF- $\alpha$ and IL- 6 and augmentation of IL-10 and IL-13. Exp Toxicol Pathol 64: 543-547, 2012.

18. Wang N, Liu X, Zheng X, Cao H, Wei G, Zhu Y, Fan S, Zhou H and Zheng J: Ulinastatin is a novel candidate drug for sepsis and secondary acute lung injury, evidence from an optimized CLP rat model. Int Immunopharmacol 17: 799-807, 2013.

19. Gao C, Li R and Wang S: Ulinastatin protects pulmonary tissues from lipopolysaccharide-induced injury as an immunomodulator. J Trauma Acute Care Surg 72: 169-176, 2012.

20. Li W, Qiu X, Jiang H, Zhi Y, Fu J and Liu J: Ulinastatin inhibits the inflammation of LPS-induced acute lung injury in mice via regulation of AMPK/NF- $\kappa$ B pathway. Int Immunopharmacol 29: 560-567, 2015.

21. Huang N, Wang F, Wang Y, Hou J, Li J and Deng X: Ulinastatin improves survival of septic mice by suppressing inflammatory response and lymphocyte apoptosis. J Surg Res 182: 296-302, 2013.
22. Shen W, Gan J, Xu S, Jiang G and Wu H: Penehyclidine hydrochloride attenuates LPS-induced acute lung injury involvement of NF-kappaB pathway. Pharmacol Res 60: 296-302, 2009.

23. Wang F, Meng Y, Zhang Y, Zhao G, Zheng X, Xiao Q and Yu Y: Ketamine reduces lipopolysaccharide-induced high-mobility group box-1 through heme oxygenase-1 and nuclear factor erythroid 2-related factor 2/p38 mitogen-activated protein kinase. J Surg Res 194: 599-613, 2015.

24. Sung YH, Shin MS, Ko IG, Kim SE, Kim CJ, Ahn HJ, Yoon HS and Lee BJ: Ulinastatin suppresses lipopolysaccharide-induced prostaglandin E2 synthesis and nitric oxide production through the downregulation of nuclear factor- $\mathrm{\kappa B}$ in BV2 mouse microglial cells. Int J Mol Med 31: 1030-1036, 2013.

25. Feng G, Sun B and Li TZ: Daidzein attenuates lipopolysaccharideinduced acute lung injury via toll-like receptor 4/NF-kappaB pathway. Int Immunopharmacol 26: 392-400, 2015.

26. Tianzhu $Z$ and Shumin W: Esculin inhibits the inflammation of LPS-induced acute lung injury in mice via regulation of TLR/NF-kB pathways. Inflammation 38: 1529-1536, 2015.

27. Kawasaki $\mathrm{T}$ and Kawai T: Toll-like receptor signaling pathways. Front Immunol 5: 461, 2014.

28. Chang Y, Huang X, Liu Z, Han G, Huang L, Xiong YC and Wang Z: Dexmedetomidine inhibits the secretion of high mobility group box 1 from lipopolysaccharide-activated macrophages in vitro. J Surg Res 181: 308-314, 2013.

29. Liu Z, Zhang J, Huang X, Huang L, Li S and Wang Z: Magnesium sulfate inhibits the secretion of high mobility group box 1 from lipopolysaccharide-activated RAW264.7 macrophages in vitro. J Surg Res 179: e189-e195, 2013

30. Liu Z, Chang Y, Zhang J, Huang X, Jiang J, Li S and Wang Z Magnesium deficiency promotes secretion of high-mobility group box 1 protein from lipopolysaccharide-activated macrophages in vitro. J Surg Res 180: 310-316, 2013.

31. Yang Q, Liu X, Yao Z, Mao S, Wei Q and Chang Y: Penehyclidine hydrochloride inhibits the release of high-mobility group box 1 in lipopolysaccharide-activated RAW264.7 cells and cecal ligation and puncture-induced septic mice. J Surg Res 186: 310-317, 2014.

32. Yamauchi Y, Izumi Y, Inoue M, Sugiura H, Goto T, Anraku M, Ohtsuka T, Kohno M, Soejima K and Nomori H: Safety of postoperative administration of human urinary trypsin inhibitor in lung cancer patients with idiopathic pulmonary fibrosis. PLoS One 6: e29053, 2011.

33. Inoue $\mathrm{K}$ and Takano $\mathrm{H}$ : Urinary trypsin inhibitor as a therapeutic option for endotoxin-related inflammatory disorders. Expert Opin Investig Drugs 19: 513-520, 2010.

34. Maciejewski R, Burdan F, Burski K, Madej B, Ziemiakowicz R, Dabrowski A and Wallner G: Selected biochemical parameters and ultrastructural picture of pancreas due to Ulinastatin treatment of experimental acute pancreatitis. Exp Toxicol Pathol 56: 305-311, 2005. 